\title{
An Economic Comparison of Prescribed Extreme Fire and Alternative Methods for Managing Invasive Brush Species in Texas: a Modeling Approach
}

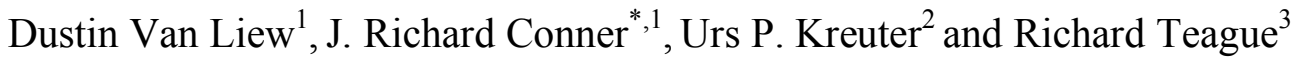 \\ ${ }^{1}$ Department of Agricultural Economics, ${ }^{2}$ Department of Ecosystem Science and Management, Texas A\&M University, \\ College Station, TX 77843, USA; ${ }^{3}$ Texas AgriLife Research, Vernon, TX 76384, USA
}

\begin{abstract}
This article presents the results of a study to determine the economic feasibility of using prescribed fire as a rangeland restoration practice on private land when ambient air temperature is greater than and humidity less than the standards endorsed by the United States Department of Agriculture (USDA) Natural Resource Conservation Service (NRCS). The objective of this study was to evaluate the economic effectiveness of using prescribed summer burns compared to more commonly used practices for managing invasive woody plants. The research incorporates four contiguous counties in the Rolling Plains, Edwards Plateau and South Texas Plains eco-regions in Texas. Focus group meetings were held with landowners and NRCS and Texas AgriLife Extension personnel to obtain information about the most common economic uses of rangeland resources by landowners, the dominant invasive brush species, and the most commonly used practices and associated costs for controlling these invasive plants. An investment feasibility model was used to compare the economic efficacy of applying extreme fire and other commonly applied treatments to manage invasive brush species in the three Texas eco-regions. The economic analysis indicated that extreme fire was economically superior in all three regions and was the only treatment alternative that resulted in positive returns on investments in the treatments. The analysis included cost-share, which indicated increased returns for extreme fire and less negative returns for alternative treatments. The results of our study have implications for the review of current NRCS technical standards with respect to prescribed fire.
\end{abstract}

Keywords: Brush control, invasive plants, prescribed fire, rangeland management.

\section{INTRODUCTION}

Rangelands cover over $40 \%$ of the Earth's surface including much of the Western United States and Texas [1]. Historically, many of the world's rangelands were open grasslands and savannas but increases in the number and density of woody plants and cacti (collectively referred to as brush) has resulted in their conversion to ever denser woodlands and cactus fields [2-6]. In Texas, rangelands have been widely transformed by brush encroachment over the past two centuries [7]. Specific changes include increases in prickly pear (Opuntia phaecantha) in the Rolling Plains; ashe and redberry juniper (Juniperus ashei Buchh. and J. pinchotii Sudw., respectively) in the Edwards Plateau; huisache (Acacia smallii Isely) in South Texas Plains; and mesquite (Prosopis glandulsa Torr.) state-wide.

Brush increases have frequently been associated with declines in herbaceous plant biomass, resulting in reduced forage availability and therefore, lower livestock carrying capacity and economic returns per unit area for livestock

\footnotetext{
*Address correspondence to this author at the Department of Agricultural Economics, Texas A\&M University, College Station, TX 77843-2124, USA; Tel: 979-845-7456; Fax: 979-845-4261;

Email: JRC@tamu.edu
}

producers [4,8]. Brush encroachment has also been associated with increased likelihood of reduced biodiversity and ecosystem resilience $[9,10]$. Failure by many ranchers to reduce livestock numbers in response to lower forage availability has led to widespread overgrazing and fuel load reduction which has accelerated the proliferation of firesensitive woody plants and cacti [11].

Historically, rangelands in Texas have been used primarily to sustain livestock but in recent years there has been an increasing shift to supply of wildlife-based recreation. As a result, wildlife-related income has equaled or surpassed income from livestock on many Texas ranches [7]. Due to the comparative advantages of open grazing resources for livestock production and rangeland with some woody plants for wildlife ranching, landowners have had to become more selective about brush management according to their specific operational objectives. In the Edwards Plateau, brush cover of about $30 \%$ has been considered optimal for maximizing income from mixed livestock production and wildlife-related hunting operations [12].

The three approaches most commonly used to treat brush in Texas include mechanical, herbicide (chemical), and prescribed fire. While these approaches vary with regard to topographic suitability, implementation techniques, and timing, the main focus of our study was their comparative economic efficacy as revealed by an investment feasibility 
model. In conducting this analysis, we were especially interested in evaluating the efficiency of using extreme fire to restore rangelands. In the past, most prescribed fires were applied during winter months [13]. However, fire is increasingly being applied during summer months when ambient temperatures and fuel loads tend to be higher and fuel moisture lower than during cooler seasons and the effect of fire on brush is reported to be more severe [7,14]. In general, fire is considered to be more cost effective but potentially more risky than the implementation of mechanical and herbicide treatment alternatives. Factors other than implementation costs must be considered to fully evaluate the relative economic efficacies of alternative brush treatments [15].

Our study addresses the following objective: To compare the economic efficacy of using extreme fire as a rangeland restoration tool compared to mechanical, herbicide, and cool season fire treatments. Specifically, our paper presents an investment feasibility model comparison of applying extreme fire to other commonly used brush treatment methods in three eco-regions in Texas: Rolling Plains, Edwards Plateau, and South Texas Plains. These three ecoregions were selected for study because they represent a north to south transect across central Texas in which brush invasions have been pervasive. Specifically, our paper presents the model results of net present value (NPV), benefit cost ratio (BC), and internal rate of return (IRR) analyses of alternative brush treatments. Although our study focuses on invasive plant management in Texas, our findings have implications for rangelands across the Western USA and around the world where fires occur periodically. Before presenting these results, we describe the invasive brush characteristics of each of the three eco-regions included in our study.

\section{Invasive Brush Characteristics by Eco-Region}

The most problematic brush species in the Rolling Plains eco-region is prickly pear (J. Gleason, NRCS, Rolling Plains TX, Personal Communication, July 2006). Recently, Ansley and Castellano [13], found that the use of extreme fire led to an $80 \%$ increase in prickly pear mortality three years after fire was applied, while cool season (low intensity) fire had little to no effect on prickly pear cover.

The most targeted invasive species in the Edwards Plateau are ashe and redberry juniper (C. Anderson, NRCS, Edwards Plateau TX, Personal Communication, July 2006). Juniper treatments are limited to mechanical and prescribed fire techniques because broadcast foliar applications of herbicides are ineffective for treating juniper [16]. Moreover, mechanical treatment methods for juniper have been found to be two to six times more costly to implement than prescribed fire [15,17,18]. Accordingly, Taylor [14] concluded that extreme fire appears to be a viable rangeland restoration option for the Edwards Plateau, but the economic efficiency of this treatment alternative has so far not been systematically evaluated.

Huisache is the main invasive brush species in the South Texas Plains, followed by mesquite (R. Gibbens, NRCS, South Texas Plains TX, Personal Communication, August 2006). Scifres and Hamilton [15] found that the probability of achieving brush mortality in South Texas with prescribed fire increased substantially when an initial mechanical or herbicide treatment was applied because this tended to increase the amount of flammable fine fuel to carry the fire. Mechanical treatments are seldom used for huisache because this species resprouts after aerial portions of the plant are removed.

Mesquite occurs on rangelands across Texas and in states to the north and west and in Mexico. It is considered a secondary problem in all three eco-regions in our study. The cost of using herbicides alone to manage mesquite can be high because repeated applications at about two year intervals are necessary to achieve significant mortality [15]. By contrast, aerial application of herbicide resulted in higher returns to investment in treatments than mechanical methods [19]. The effectiveness of using prescribed fire for treating mesquite has been substantially researched [20]. In North Texas, researchers found that prescribed fire could be used to treat mesquite less expensively than alternative brush treatments but, to be effective, fire must be applied more frequently than other treatments $[21,22]$. In addition, if the use of herbicides is chosen as the initial treatment option, the application of prescribed fire as a maintenance treatment was found to be economically more effective when applied 10 years rather than 15 or 20 years after the initial herbicide treatment was applied [23]. Similarly, in South Texas fall and winter burning were found to effectively reduce brush canopy cover, and both options resulted in greater brush reduction when fire was applied after an initial mechanical treatment [24].

\section{MATERIALS AND METHODOLOGY}

The study focused on four contiguous counties in the Rolling Plains, Edwards Plateau and South Texas Plains ecosystems of Texas as shown in Fig. (1). The counties were selected, based on advice from Texas AgriLife Extension agents, because they represented a contiguous block of the dominant vegetation composition in each eco-region.

\section{Data Collection and Analytical Scenarios}

To achieve the objective of comparing the economic effectiveness of using extreme fire to other brush management practices, we first obtained relevant information for each of the three four-county study sites. Since substantial amounts of the required data are not published, we used focus group meetings [25] to obtain key informant consensus about the primary information required for each eco-region.

Focus group meetings were held in each eco-region during July and August 2006 and included NRCS representatives, Texas AgriLife Extension personnel, and landowners. Information obtained during these meetings and during follow-up communications with NRCS and Texas AgriLife Extension personnel included descriptions of the most common rangeland production systems, the most commonly used brush treatments, the costs of applying these treatments and the average livestock grazing and wildlife hunting lease rates prevailing in each eco-region. Herbaceous forage response data (i.e., changes in grazing capacity per unit area) following brush treatments were obtained from previous studies in the Rolling Plains [26,27] (R. Teague, Texas AgriLife Research, Vernon TX, Personal Communication, February 2007) and the Edwards Plateau 


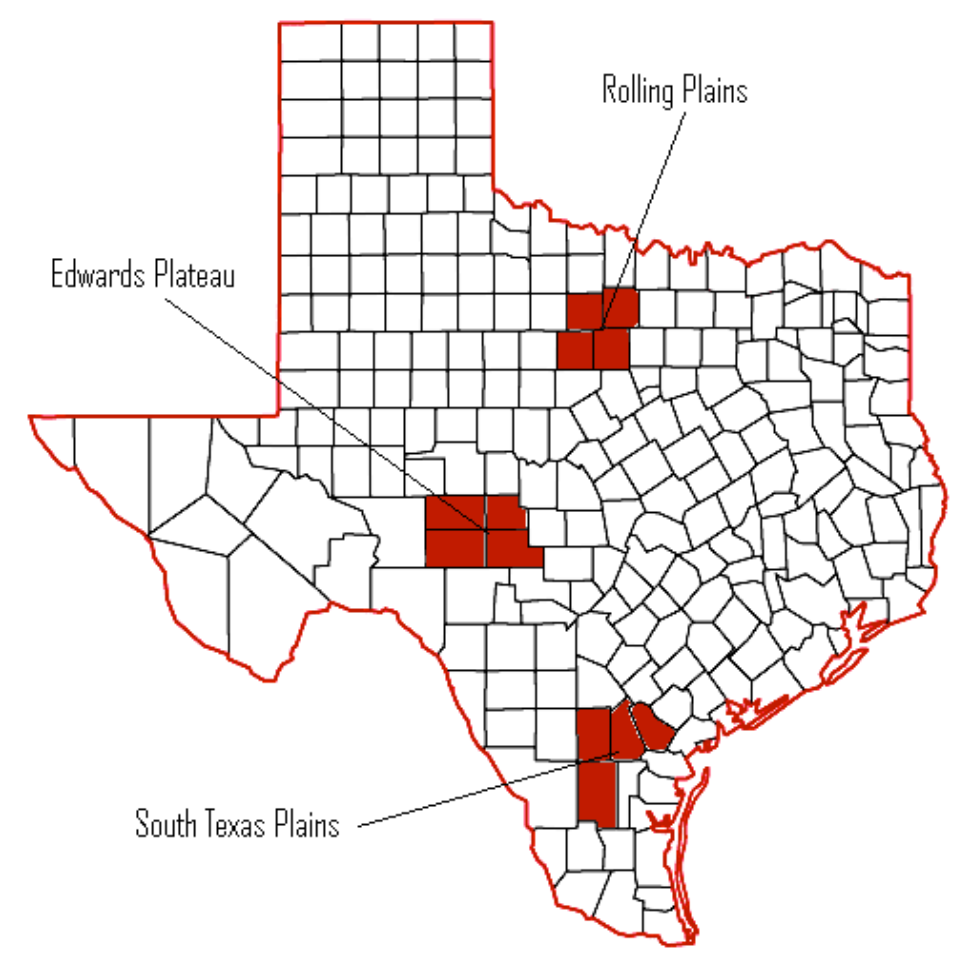

Fig. (1). Study area counties in Texas: Rolling Plains - Shackelford, Stephens, Throckmorton and Young; Edwards Plateau - Kimble, Menard, Schleicher and Sutton; and South Texas Plains - Bee, Duval, Live Oak and McMullen.

and South Texas Plains [28,29]. Based on the information thus obtained, the following treatment scenarios were established as the basis for the economic analysis.

The brush treatments evaluated in this study consisted of an initial treatment and a series of follow-up treatments at specified intervals over a twenty-year planning horizon. Using the information from previous research $[13,15,16,21$, $26,27]$ the extreme fire treatment programs were designed to produce essentially the same herbaceous forage response as the more commonly used mechanical or chemical practice for each specific species, location and canopy density combination evaluated. In the Rolling Plains and Edwards Plateau, initial brush treatments included for analysis consisted of mechanical, herbicide and extreme fire treatments, each followed by cool season fires every six years thereafter as a maintenance treatment. In the South Texas Plains, initial treatments included herbicide and extreme fire only (mechanical treatment for huisache and mesquite being largely ineffective). The initial herbicide treatment is followed with a cool season fire the following year and then every four years thereafter, while the initial extreme fire treatment is followed by cool season fire at four-year intervals. The difference in maintenance fire frequencies among the eco-regions is due the longer growing season and greater herbaceous production in the South Texas Plains and the associated need for more frequent maintenance treatments [15] (J. Ansley, Texas AgriLife Research, Vernon TX, Personal Communication, February 2007).

Brush cover was categorized as heavy or moderate. Heavy brush cover is represented by greater than $50 \%$ canopy cover, and moderate brush cover by $25 \%$ cover for all woody species. By contrast, heavy prickly pear cover is represented by greater than $20 \%$ canopy cover and moderate cover by 10 to $20 \%$ cover.

Brush treatment response analyses were based on data from previous research aimed at estimating livestock carrying capacity changes following brush treatment. These analyses provide estimates of increases in livestock grazing capacity in animal unit years per hectare (AUY ha ${ }^{-1}$ ) due to the initial treatment effect and the longevity of that treatment. They also illustrate how the maintenance treatments extend the life of the initial treatment and what will happen to carrying capacity if brush management practices are not instituted. An example for moderately dense mesquite is provided in Fig. (2).

Pretreatment carrying capacity estimates were based on the expert opinion of long-term researchers in each ecoregion (R. Teague, J. Ansley, C. Taylor and W. Hanselka, Texas AgriLife Research and Extension, Personal communication, March 2007). For the Edwards Plateau and South Texas Plains the base carrying capacity was set at 20.23 ha $\mathrm{AUY}^{-1}\left(0.0494 \mathrm{AUY} \mathrm{ha}^{-1}\right)$ for land with heavy brush cover and 12.14 ha $\mathrm{AUY}^{-1}\left(0.0824 \mathrm{AUY} \mathrm{ha}^{-1}\right)$ for land with moderate brush cover for all brush species. For the Rolling Plains, base carrying capacity of rangelands with mesquite was set at 8.09 ha $\mathrm{AUY}^{-1}\left(0.1236 \mathrm{AUY} \mathrm{ha}^{-1}\right)$ for heavy cover and 7.00 ha $\mathrm{AUY}^{-1}\left(0.1429 \mathrm{AUY} \mathrm{ha}^{-1}\right)$ for moderate cover, and for rangelands with prickly pear it was set at 7.65 ha $\mathrm{AUY}^{-1}\left(0.1307 \mathrm{AUY} \mathrm{ha}^{-1}\right)$ for heavy cover and 6.8 ha $\operatorname{AUY}^{-1}\left(0.1471 \mathrm{AUY} \mathrm{ha}^{-1}\right)$ for moderate cover. The higher carrying capacities for the Rolling Plains reflects the relatively lower impact of brush cover on herbaceous forage production per unit area in this eco-region compared to the two other study areas. 


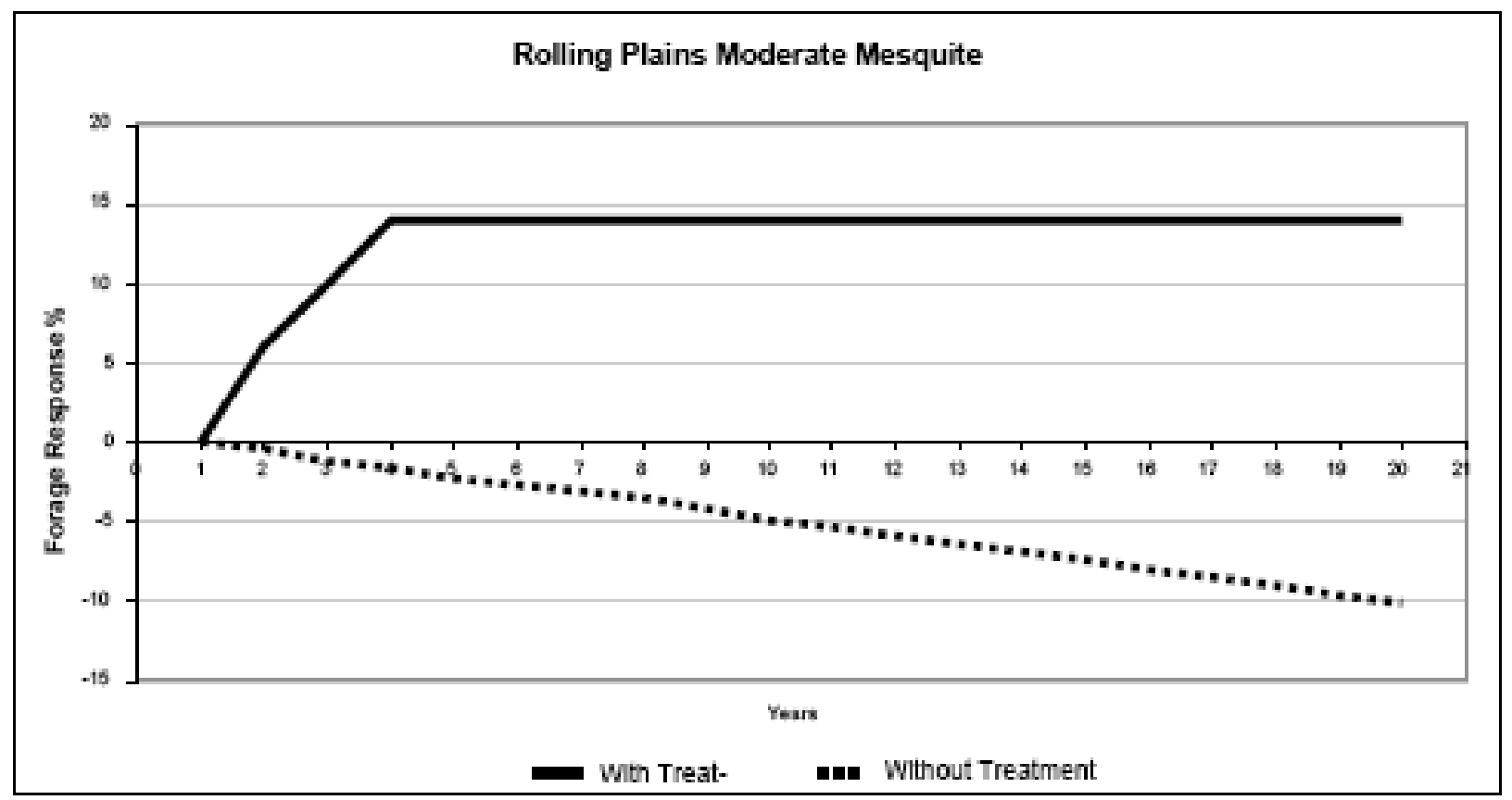

Fig. (2). Response curve graph. Showing forage response with (solid line) and without (hashed line) treatment for moderate mesquite in the Rolling Plains, Texas.

In conducting the economic analysis, several assumptions were made to facilitate comparison of the alternative brush management treatments. First, the unit of analysis is an operating ranch of 404.7 hectares $(1,000$ acres $)$ in size. Second the planning horizon for which the analysis was conducted is twenty years. Third, a discount rate of $6 \%$ was used to obtain the present value of all projected costs and revenues incurred during the 20 year planning period. The $6 \%$ rate is approximately two times the inflation rate and two to three times the risk-free interest rate commonly paid on simple savings accounts. Using a discount rate higher than the prevailing rate of return on risk free investments is warranted due to the higher risk associated with investments in range management practices [17]. A sensitivity analysis indicated that the choice of a lower discount rate (two or four percent) did not affect the relative economic efficiencies of alternative brush treatment options.

In addition, to simplify the comparative economic analysis of alternative brush treatment approaches, it was assumed that the entire ranch is operated by a livestock grazing lessee who is permitted to use a stocking rate that equals the livestock carrying capacity. Furthermore, it was assumed that the grazing lease rate paid by the lessee is based on the number of Animal Unit Equivalents (AUE) represented by the carrying capacity. Therefore, the annual revenue received by the landowner changes in direct proportion to the changes in livestock carrying capacity resulting from implementation of the brush control practices.

Finally, the analyses of each brush management treatment, are conducted both with and without a $50 \%$ cost share to the landowner for implementing the brush treatments. This ratio assumes that half the brush treatment cost would be paid for by public funding and it is based on the cost-sharing ratio commonly used in federal conservation programs, such as the Environmental Quality Incentives Program (EQIP).

\section{Brush Treatments}

Within each of the three eco-regions included in the study, extreme fire applications to both moderate and heavy canopy cover were compared with the most commonly used alternative treatment for the most problematic brush species previously identified and for mesquite. Details of each initial "alternate" brush treatment are provided in Table 1.

In the Rolling Plains, the alternate treatments evaluated for moderate and heavy prickly pear cover were individual plant treatment (IPT) using picloram plus flurozypyr (Surmount $\left.{ }^{\circledR}\right)$ and aerial application of picloram, respectively. The alternate treatments for moderate and heavy cover of mesquite were basal IPT and aerial applications of triclopyr plus clopyralid $\left(1: 1\right.$ Remedy $\left.{ }^{\circledR}+\operatorname{Reclaim}{ }^{\circledR}\right)$ mixes, respectively.

In the Edwards Plateau, the alternate treatment for moderate and heavy cover of redberry juniper, a basal sprouting species, was mechanical grubbing and stacking. Grubbing alone was also analyzed for heavy cover. The alternate treatments for ashe juniper, a non-sprouting species, included ground-level cutting and stacking for moderate cover and mechanical grubbing and stacking plus grubbing alone for heavy cover. The alternate treatments for moderate and heavy mesquite were IPT using a basally applied diesel/ Remedy ${ }^{\circledR}$ mix and aerial application of 1:1 Remedy ${ }^{\circledR}+$ Reclaim ${ }^{\circledR}$ mix, respectively.

In the South Texas Plains, the alternate treatments for moderate and heavy cover of huisache were IPT using a basally applied diesel/Remedy ${ }^{\circledR}$ mix and aerially applied picloram and 2,4-D (Grazon $\left.{ }^{\circledR} \mathrm{P}+\mathrm{D}\right)$, respectively. The 
Table 1. Detailed Description of Initial Alternate Brush Treatment for Each of the Three Eco-Systems Included in the Study

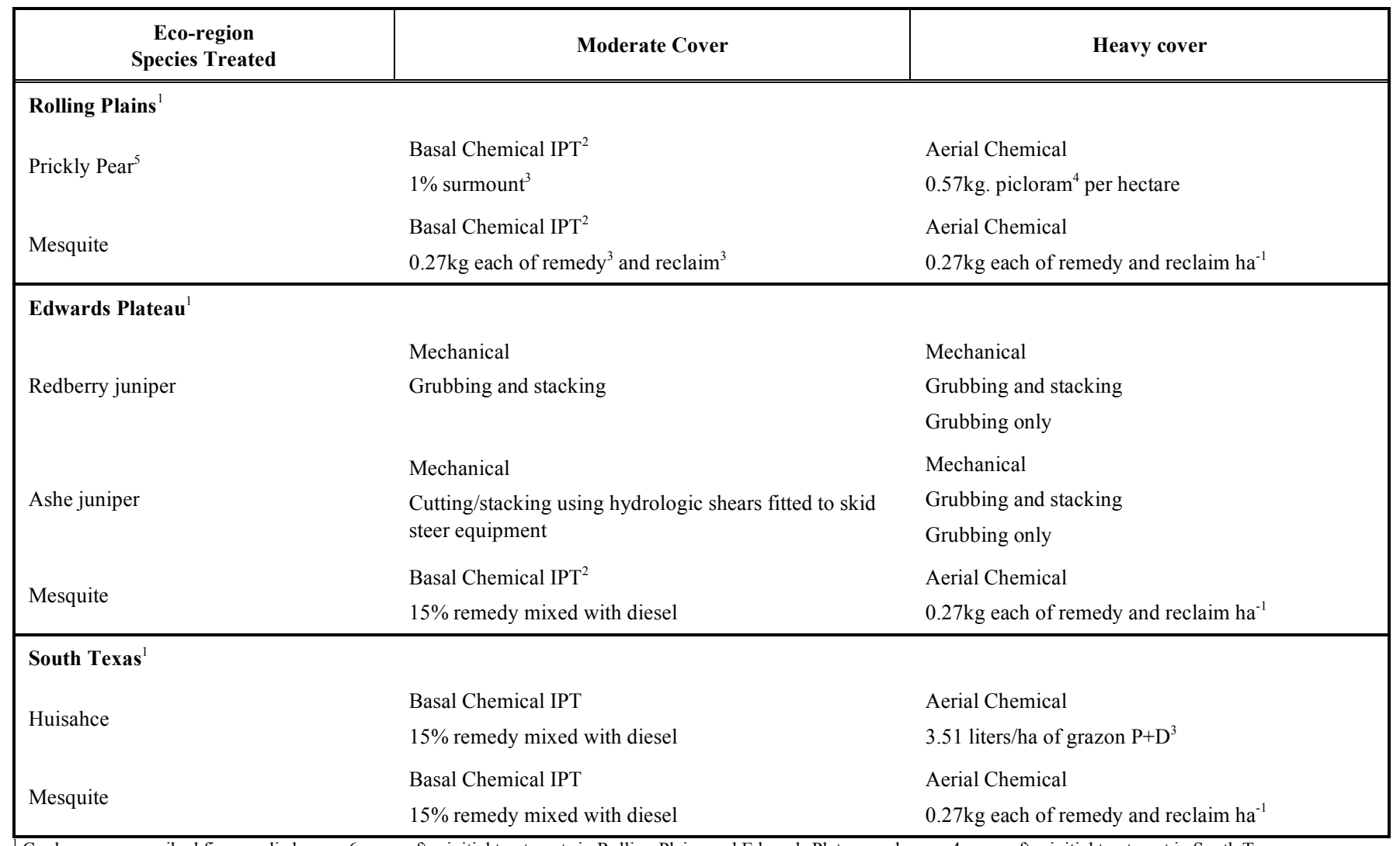

${ }^{1}$ Cool season prescribed fires applied every 6 years after initial treatments in Rolling Plains and Edwards Plateau and every 4 years after initial treatment in South Texas.

${ }^{2}$ Individual plant treatment.

${ }^{3}$ Manufactured by Dow AgroSciences, LLC

${ }^{4}$ Manufactured by DuPont Agricultural Products

${ }^{5}$ Prickly pear heavy cover is greater than $20 \%$ and moderate cover is between 10 and $20 \%$

alternate treatments for moderate and heavy mesquite cover were the same as those used for the Edwards Plateau ecoregion.

\section{Investment Feasibility Model}

The comparative economic analysis of using prescribed extreme fire, mechanical and chemical treatments as brush control practices was conducted using NPV, BC ratio and IRR over a 20 -year planning period as revealed by an investment feasibility model. NPV converts the values of future benefits and costs to present values as follows [30]:

$$
N P V=\sum_{t=0}^{n} \frac{\left(B_{t}-C_{t}\right)}{(1+i)^{y}}
$$

where $B_{t}-C_{t}=$ net future value in year $t, i=$ discount rate, $n$ $=$ planning horizon and $\mathrm{t}=$ the specific year during the planning horizon.

The investment feasibility model was parameterized for each specified brush species, brush density, and brush mana-gement combination in each eco-region. Data required to parameterize the model included costs and year incurred for initial and maintenance brush management actions, livestock carrying capacity for each year of the planning period both with and without implementation of the brush control practices, annual costs and revenues associated with operating the grazing lease and the appropriate discount rate for future costs and revenues. Once parameterized, the model was used with the specified data to calculate the NPV, BC, and IRR for the investment in the specific brush management scenario over the 20 year planning period.

An investment is considered to be economically feasible when NPV $\geq 0$ (the sum of discounted future returns are equal to or exceed the sum of discounted future costs). NPV is considered superior to other metrics of economic gains from range improvement practices because it accounts for the time value of money and provides a dollar value for the investment [17]. By contrast, $\mathrm{BC}$ analysis provides a simple ratio of the present value of future benefits and costs $(\mathrm{BC}>1$ implies economic feasibility). IRR provides a measure of the income earning potential of an investment and is the ratio of the average annual earnings divided by the sum of discounted costs of the investment expressed as a percent. The IRR is an indicator of efficiency or quality of an investment, allowing for comparisons to alternate capital investments.

Break even data for alternative brush treatments are also presented. These data provide the amount of subsidy that would be needed to allow the landowner's investment in brush management to break even. The breakeven point was calculated by adding the NPV to the total investment cost. In addition, a second breakeven point was calculated with the assumption that the landowner has received $50 \%$ cost share for implementing a brush management project. 


\section{RESULTS}

\section{Economic Feasibility}

Results from the investment feasibility model are presented in tabular format. Table 2 presents the total cost, $\mathrm{NPV}, \mathrm{B} / \mathrm{C}$ ratio, and IRR of applying extreme fire and the specified alternate brush treatments (described in Table 1) for the primary problem plant species and mesquite in each eco-region. NPV values are presented on a $\$$ per hectare basis.

In the Rolling Plains extreme fire proved to be economically feasible for controlling heavy prickly pear cover,

Table 2. Total Cost, Net Present Value (NPV), Benefit-Cost Ratio (B/C) and Internal Rate of Return (IRR) of Applying Extreme Fire and Alternate Brush Treatments to the Primary Problem Plant Species and Mesquite in Each Eco-Region (Refer to Table 1 for Specification of Alternate Treatments)

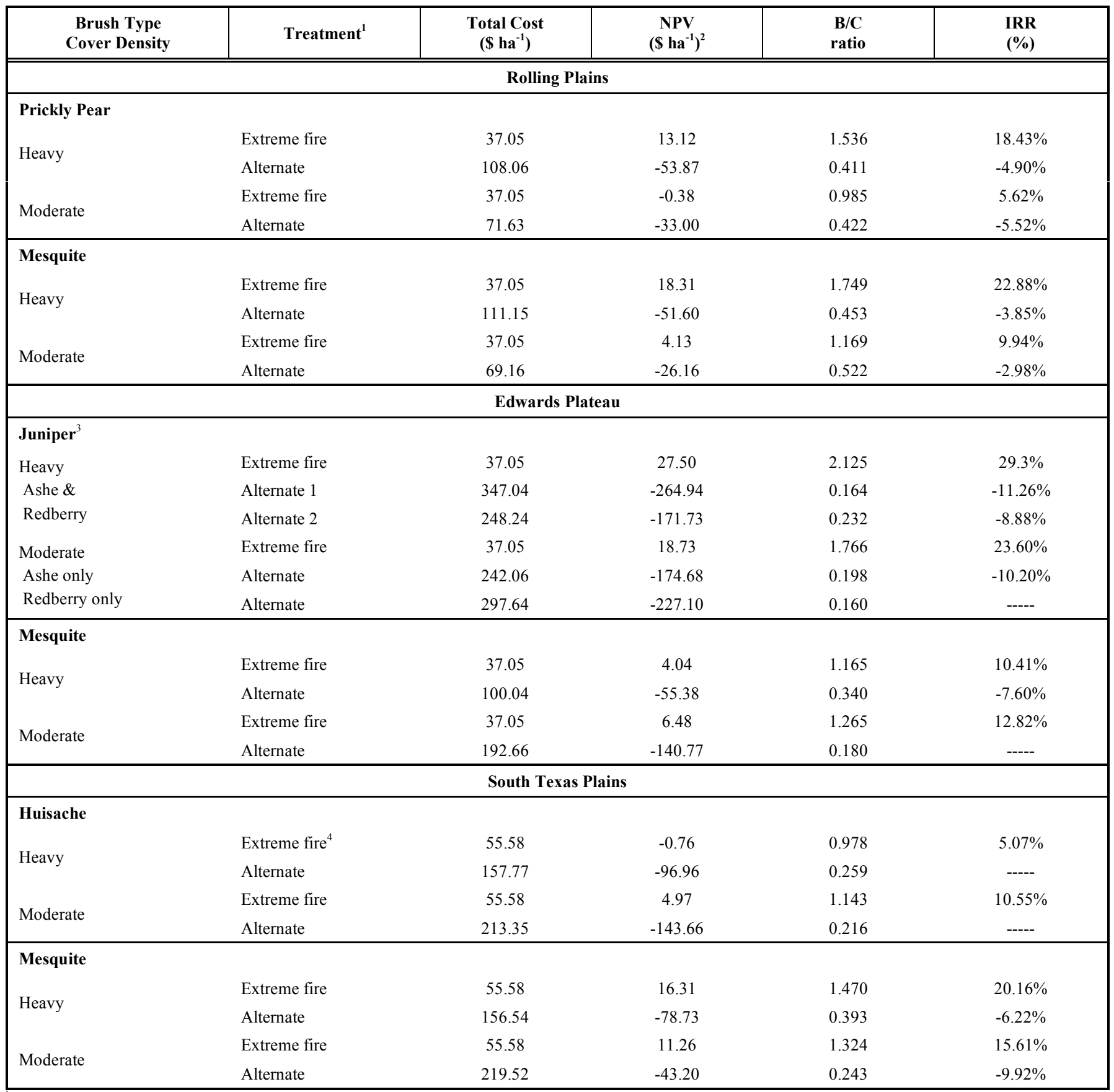

See Table 1 for description of alternate treatments.

If NPV $<0$, some cost sharing would be necessary to allow landowner to break even on total investment cost; and if NPV $>0$, the resulting "profit" could be invested in further rangeland treatment.

Alternate treatments for heavy cover of both Ashe and Redberry juniper include grubbing only, and grubbing and stacking, whereas alternate treatments for moderate cover of these species include treeshears and grubbing and stacking, respectively.

${ }^{4}$ The higher cost for extreme fire in the South Texas Plains is due to more frequent maintenance fires. 
$\left(\mathrm{NPV}=\$ 13.12 \mathrm{ha}^{-1}[>0] ; \mathrm{BC}>1\right.$; IRR $\left.>6 \%\right)$ while for moderate prickly pear cover, extreme fire was economically marginal $\left(\mathrm{NPV}=-\$ 0.38 \mathrm{ha}^{-1}\right)$. By contrast, the alternative herbicide treatments for heavy and moderate cover prickly pear produced substantially negative NPVs (-\$53.87 and $\$ 33.00 \mathrm{ha}^{-1}$, respectively). Similarly, extreme fire was economically superior to the alternative herbicide treatments for heavy cover mesquite ( $\$ 18.31 \mathrm{vs}$. $-\$ 51.60$ ha-1) and for moderate cover mesquite ( $\left.\$ 4.13 v s .-\$ 26.16 \mathrm{ha}^{-1}\right)$.

In the Edwards Plateau, extreme fire treatments for heavy and moderate juniper cover were likewise economically feasible $\left(\mathrm{NPV}=\$ 27.50\right.$ and $\$ 18.73, \mathrm{ha}^{-1}$, respectively), while all four alternate mechanical treatments for heavy and moderate juniper cover resulted in substantially negative NPVs and are economically not feasible (Table 2). The application of extreme fire to heavy and moderate cover mesquite also produced positive NPVs (\$4.04 and \$6.08, respectively), while the alternate herbicide treatments produced substantially negative NPVs (Table 2).

In the South Texas Plains, neither extreme fire nor the alternate treatment for heavy huisache cover were economically feasible (NPV $=-\$ 0.76$ and $-\$ 96.96 \mathrm{ha}^{-1}$, respectively). By contrast, extreme fire for treating moderate huisache cover was found to be economically feasible, $\left(4.97 \mathrm{ha}^{-1}\right)$ but the alternate treatment was not (Table 2). Extreme fire was found to be economically feasible for the treatment of both heavy and moderate mesquite cover $(\mathrm{NPV}=\$ 16.31$ and $\$ 11.64 \mathrm{ha}^{-1}$, respectively), but the alternate herbicide treatments produced negative NPVs (Table 2).

\section{Effect of Cost Sharing for Primary Problem Species}

Cost-sharing may be necessary to encourage landowners to adopt rangeland management practices that produce socially desirable outcomes in cases where private landowner benefits do not fully offset the associated costs of implementation. Table 3 presents the break even value, 50\% cost sharing value and NPV with 50\% cost-sharing (adjusted NPV) for each woody plant treatment scenario previously described. The break even value indicates the largest total cost for a treatment scenario that would allow a landowner to break even (result in an NPV $=0$ ), assuming a $6 \%$ discount rate. It is obtained by adding the NPV value to the Total Cost values shown in Table 2 . The NPV values associated with each treatment, both with and without $50 \%$ cost-sharing, are compared for the primary problem species in each ecoregion and across eco-regions for mesquite.

When $50 \%$ cost share was applied to treatments for controlling prickly pear in the Rolling Plains, NPV of using extreme fire increased by $140 \%$ for dense prickly pear cover and for moderate prickly pear cover the NPV became positive (Table 3 ). In the case of the alternate herbicide treatments, a 50\% cost share resulted in the NPV becoming just greater than zero for both heavy and moderate prickly pear cover.

The inclusion of a $50 \%$ cost-share for controlling juniper in the Edwards Plateau resulted in the NPVs associated with the use of extreme fires to increase by $67 \%$ for heavy cover and $104 \%$ for moderate cover. By contrast the NPVs for all alternate mechanical treatments remained negative and thus economically infeasible when $50 \%$ cost-sharing was incorporated (Table $\mathbf{3}$ ).

Similar to prickly pear in the Rolling Plains and juniper in the Edwards Plateau, the inclusion of a $50 \%$ cost-share for the application of extreme fire to treat huisache in the South Texas Plains resulted in all NPVs becoming positive (Table 3). By contrast, the alternate herbicide treatments for huisache produced a negative NPV even when a 50\% costshare was included thereby rendering it economically infeasible even with substantial cost sharing.

\section{Comparative Economic Efficiency of Alternative Treatments for Mesquite}

Mesquite was reported to be a problematic invasive species across all three of the eco-regions included in this study. Therefore, the economic efficiencies of alternative treatments for this species, both without and with $50 \%$ costsharing, are compared across the three eco-regions.

The use of extreme fire to treat mesquite was found to be economically feasible (NPV $>0$ ) without cost-sharing in all three eco-regions (Table 2). However, while applying extreme fire to heavy mesquite cover produced a $450 \%$ greater NPV in the Rolling Plains than in the Edwards Plateau ( $\$ 18.30$ vs. $\$ 4.05 \mathrm{ha}^{-1}$ ), it produced a $60 \%$ greater NPV when extreme fire was applied to moderate mesquite cover in the Edwards Plateau than in the Rolling Plains ( $\$ 6.48$ vs. $\left.4.13 \mathrm{ha}^{-1}\right)$. This difference is due to the greater forage response of using extreme fire to treat heavy mesquite in the Rolling Plains compared to forage responses under moderate mesquite cover in both eco-regions. In addition, because mesquite is generally less invasive in the Edwards Plateau than the Rolling Plains eco-region, the anticipated forage response to the use of extreme fire to treat dense mesquite is expected to be lower in the Edwards Plateau. The use of extreme fire for the treatment of moderate mesquite produced greater NPV $\left(\$ 11.26 \mathrm{ha}^{-1}\right)$ in the South Texas Plains due to higher grazing and hunting-lease rates than in either the Rolling Plains or the Edwards Plateau. When $50 \%$ cost share was included in the economic analysis, the economic efficiency of extreme fire treatments for mesquite increased in all three eco-regions.

In contrast to extreme fire, the alternative herbicide treatments for both heavy and moderate mesquite cover produced negative NPVs in all three eco-regions when no cost-share was applied, although the Rolling Plains resulted in the least negative NPVs (Table 2). This suggests that it would be less costly to treat mesquite with herbicide in the northern most study site. However, when 50\% cost sharing was added, herbicide treatments in the Rolling Plains became economically feasible (NPV >0) (Table 3). By contrast, a $50 \%$ cost share would be insufficient to provide a positive return to landowners in the Edwards Plateau and the South Texas Plains with aerial herbicide treatment of heavy mesquite cover and the IPT herbicide treatment of moderate mesquite cover. In the case of aerial herbicide application for dense mesquite in the South Texas Plains, 50\% cost share is only marginally insufficient to produce a positive NPV. The difference between the Rolling Plains and the Edwards Plateau/South Texas Plains is due to the higher livestock carrying capacity in the north. 
Table 3. Per Hectare Total Treatment Cost, Break Even, $50 \%$ Cost Sharing Value and Net Present Value (NPV) with 50\% CostSharing (All in $\$ \mathrm{ha}^{-1}$ ) for Extreme Fire and Alternate Brush Treatments for Primary Problem Plant Species and Mesquite in Each Eco-Region (Refer to Table 1 for Specification of Alternate Treatments)

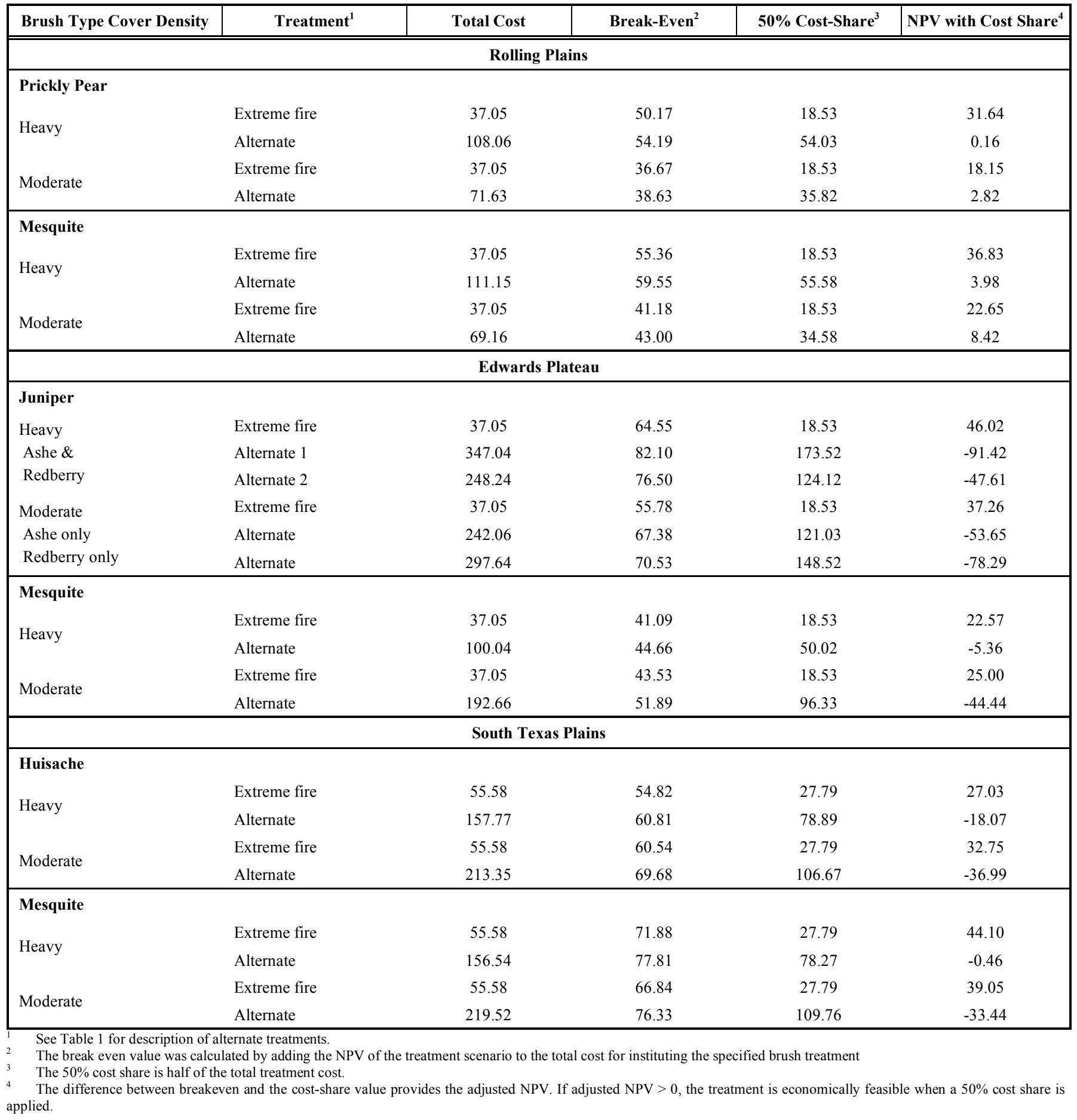

\section{DISCUSSION AND CONCLUSION}

Our comparative economic analysis of alternative methods for treating primary invasive plants and mesquite in the Rolling Plains, Edwards Plateau and South Texas Plains indicates that, based on the specified assumptions, the use of extreme fire as an initial invasive woody plant treatment is economically superior to all of the commonly used mechanical and herbicide-based methods. In many cases, the rates of return from investments in brush management using extreme fire were double or triple the assumed discount rate. Only in the case of moderate prickly pear cover in the Rolling Plains and heavy huisache cover in the South Texas Plains was the use of extreme fire found to be economically marginal and in both cases would be viable with a minimal amount of cost sharing. The use of extreme fire was found to be an economically efficient method for treating both heavy 
and moderate cover mesquite in all three eco-regions, especially in the Rolling Plains and South Texas Plains ecoregions. By contrast to the use of extreme fire, all of the alternative mechanical or herbicide-based treatments for prickly pear, juniper, huisache, and mesquite were found to be economically infeasible; all produced substantially negative NPVs when no cost share was added. Despite the clear economic superiority of using extreme fire to restore rangelands across all three eco-regions, two caveats need to be added.

First, we did not take into account weather-related risk of not being able to institute a fire regime, which could reduce the NPV and possibly even make the practice infeasible in some cases. If rainfall is below average in the period leading up to the application of extreme fire, there is a good probability there will be insufficient fuel load to carry fire. Protracted delays in the application of fires may necessitate the use of alternative mechanical or herbicide-based treatments to ensure that invasive plants are maintained at manageable levels. The effect of the probability of deferring fire on the economic efficiency of using this brush control tool needs to be further investigated. At the same time, weather-related risks of not being able to apply herbicides or use mechanical practices at optimal times also need further study to provide a more complete assessment of the relative economic efficiencies of extreme fire and alternate brush management treatments.

Second, even if the application of extreme fire is the only economically feasible option for restoring prickly pear or woody-plant invaded rangelands, the reluctance of many landowners to use this tool cannot be ignored. If landowners remain reluctant to apply extreme restoration fires on their land, especially during summer when prescribed fires are more likely to be extreme and the risk of damage from escaped fires is likely to be significantly elevated [31], but it is socially desirable to maintain bio-diverse, ecologically resilient and productive rangelands, it may be necessary to provide public funding to assist landowners in implementing alternative rangeland restoration practices that they perceive to be less risky. The implementation of land improvement programs, such as EQIP, already addresses this need. Accordingly, we also addressed the effectiveness of costsharing on the economic feasibility of alternative invasive plant management practices to the landowner. Assuming a $50 \%$ cost-share ratio, we found that cost sharing would make mechanical and chemical treatments for prickly pear and mesquite in the Rolling Plains economically feasible for the private landowner. However, in the Edwards Plateau and the South Texas Plains, a higher level of cost sharing would be necessary to ensure that landowners break even when applying the most commonly used juniper, huisache and mesquite control techniques. This is consistent with the higher cost-sharing that is commonly provided to landowners who are improving endangered species habitat in the Leon River watershed, for example, where cost-sharing of $80 \%$ is common.

An alternative to providing public funding to facilitate the implementation of potentially less risky but economically more costly rangeland restoration practices is to educate landowners about the use of prescribed fire, including extreme fire. In Texas, and increasingly also in other states to the north, the establishment of prescribed burning associations has significantly enhanced landowner perceptions about the safe use of extreme prescribed fire [32]. However, integrated data about the social, ecological an economic dimensions of extreme fire to promote this tool as a safe, effective and efficient management tool has so far been lacking. This knowledge gap is currently being addressed in an extensive research project across Texas of which the economic assessment reported here is an integral part. The results of the ecological and social dimension of this project will be reported in forthcoming publications.

In conclusion, from an economic perspective, our study suggests that extreme fire is efficient and economically superior to other treatment options for restoring rangelands that have become infested with invasive brush species in all three eco-regions in Texas. The use of extreme fire as a rangeland restoration tool is still relatively new and minimally used. However, the results of our study, should contribute to the growing interest by landowners in using this method for restoring rangelands. In addition the results should assist in the review of current NRCS technical standards with respect to prescribed fire.

\section{CONFLICT OF INTEREST}

None declared.

\section{ACKNOWLEDGEMENT}

Research was funded in part with a USDA Conservation Innovation Grant provided by the Natural Resource Conservation Service (NRCS) (Grant \# 68-3A75-5-180).

\section{REFERENCES}

[1] Agricultural Research Service, United States Department of Agriculture [homepage on the Internet]. Washington, DC [cited 2008 July 16]. Available from: http://www.ars.usda.gov

[2] Archer S, Smeins FE. In: Heitschmidt RK, Stuth JW, Eds. Ecosystem Level Processes. Grazing management: an ecological perspective. Timber Press: Portland 1991; 10-40.

[3] Ansley RJ, Pinchak WE, Ueckert DN. Changes in redberry juniper distribution in Northwest Texas. Rangelands 1995; 17: 49-53.

[4] Archer S. Herbivore mediation of grass-woody interactions. Tropical Grasslands 1995; 29: 218-35.

[5] Collins SL, Knapp AK, Briggs JM, Blair JM, Steinaur EM. Modulation of diversity by grazing and mowing in native tall grass prairie. Science 1998; 280: 745-7.

[6] Teague WR, Dowhower SL. Drought and grazing patch dynamics under different grazing management. J Arid Environ 2004; 58: $97-$ 117.

[7] Hamilton WT, McGinty A, Ueckert DN, Hanselka CW, Lee MR. Eds. Brush management past, present, future. College Station, TX 77843, Texas: A\&M University Press 2004.

[8] Westoby MB, Walker B, Noy-Meir I. Opportunistic management for rangelands not at equilibrium. J Range Manag 1989; 42: 26674

[9] Knopf FL. Avian assemblages on altered grasslands. Stud Avian Biol 1994; 15: 247-25.

[10] Peterson G, Allen GR, Holling CS. Ecological resilience, biodiversity and scale. Ecosystems 1998; 1: 6-18.

[11] Scifres CJ. Brush Management. College Station, TX: Texas A\&M University Press 1980; p. 360.

[12] Thurow T, Thurow AP, Taylor C Jr., Conner R, Garriga M. Environmental and economic tradeoffs associated with vegetation management on the Edwards Plateau. Paper presented at the Juniper Symposium, Texas Agricultural Experiment Station, San Angelo, January 9-10, 1997. 
[13] Ansley RJ, Castellano MJ.Prickly pear cactus response to summer and winter fires. Rangeland Ecol Manag 2007; 60: 244-52.

[14] Taylor C. Prescribed burning cooperatives: empowering and equipping ranchers to manage rangelands. Rangelands 2005; 27(1): 18-23.

[15] Scifres CJ, Hamilton WT. Prescribed burning for brushland management: the South Texas example. College Station, TX: Texas A\&M University Press 1993; p. 312.

[16] Lyons RK, Owens MK, Machen RV. Juniper biology and management in Texas [monograph on the internet]. Texas A \& M Agr Ext Serv 1998 [cited 2008 July 15]. Available from: http://wildlife.tamu.edu/publications/B6074.pdf

[17] Workman JP. Range economics. MacMillan Publishing Co: New York, NY, 1986; p. 216.

[18] Ansley RJ, Rasmussen GA.Managing native invasive juniper species using fire. J Weed Technol 2005; 19(3): 517-22.

[19] Whitson RE, Scifres CJ. Economic comparison of honey mesquite control methods with special reference to the Texas Rolling Plains. J Range Manag 1981; 34: 415-20.

[20] Ansley RJ, Jones DL, Tunnell TR, Kramp BA, Jacoby PW. Honey mesquite canopy responses to single winter fires: relation to fine fuel, weather andfire temperature. Int J Wildland Fire 1998; 8: 24152.

[21] Teague WR, Borchardt B, Ansley J, Pinchak B, Cox J, Foy JK, McGrann J. Sustainable management strategies for mesquite rangeland: The Waggoner Kite Project. Rangelands 1997; 19(5): 48 .

[22] Teague WR, Ansley RJ, Kreuter UP, Pinchak WE, McGrann JM. Economics of managing mesquite in North Texas: a sensitivity analysis. J Range Manag 2001; 54: 553-60.

[23] Teague WR, Kreuter U, Ansley J, McGrann J. Economics of fire as a follow-up to herbicide treatment of mesquite. Proceedings of the $7^{\text {th }}$ International Rangeland Congress, Durban, South Africa. 26 July-1 August 2003; pp. 1973-75.

[24] Box TW, White RS. Fall and winter burning of South Texas brush ranges. J Range Manag 1969; 22(6): 373-76.

[25] Krueger RA, Casey MA. Focus groups: apractical guide for applied research. Sage Publications Inc.: Thousand Oaks, CA 2000; p. 184.

[26] Dugas W, Ed. Brush management/ water yield feasibility studies for eight watersheds in Texas [monograph on the internet]. College Station: Texas Water Research Institute; 2000 [cited 2008 July 19]. Available from: http://www.brc.tamus.edu/blackland/dugas/index. html

[27] Ansley RJ, Castellano MJ. Strategies for savanna restoration in the southern great plains: effects of fire and herbicides. Restoration Ecol 2006; 14: 420-8

[28] Hughes RF, Archer SR, Asner GP, et al. Changes in above ground primary production and carbon and nitrogen pools accompanying woody plant encroachment in a temperate savanna. Glob Change Biol 2006; 12: 1733-47.

[29] Taylor CA. In: Auken OV, Ed. Ecological consequences of using prescribed fire and herbivory to manage Juniperus encroachment. Western North American Juiperus communities: a dynamic vegetation type. USA: Springer 2008; pp. 239-52.

[30] Odellion Research [homepage on the internet]. Austin, TX: Odellion Research, Inc.; [Cited 2007 May 15, 2007]. Available from: http://www.odellion.com/pages/online\%20community/NPV/ financialmodels_npvdefinition.htm.

[31] Yoder J. Liability, regulation, and endogenous risk: the incidence and severity of escaped prescribed fires in the United States. J Law Econ 2008; 51: 297-326.

[32] Kreuter UP, Woodard JB, Taylor CA, Teague WR. Perceptions of Texas landowners regarding fire and its use. Rangeland Ecol Manag 2008; 61: 456-64.

(C) Liew et al.; Licensee Bentham Open.

This is an open access article licensed under the terms of the Creative Commons Attribution Non-Commercial License (http://creativecommons.org/licenses/by-nc/3.0/) which permits unrestricted, non-commercial use, distribution and reproduction in any medium, provided the work is properly cited. 